\title{
Study on Risks in Mortgage Financing of Rural Land Management Right
}

\author{
Peng Yan $^{1}$,Liu Wen-bin²*, Tan Chang ${ }^{1}$ \\ $\left({ }^{1}\right.$ School of Business Administration,Zhongnan University of Economics and \\ Law,Wuhan,430073,China) \\ ( ${ }^{2}$ Basic Department,Wuhan Technology and Business University, Wuhan,430065,China) \\ (*Corresponding Author: Liu Wen-bin, email:812926096@qq.com)
}

Keywords: Reform of rural property rights, mortgage on rural land management right, rural finance, risk issues

\begin{abstract}
With the continuous reform of the property rights system in rural China, pilot projects of mortgage financing for rural land management right have been conducted in large areas across the country. This is not only an innovation in the development of rural finance in China, but also a great impetus to the development of rural economy. However, with the rapid progress of pilot projects, the issues of credit risk, disposal of rural land and social risks have become increasingly prominent. These risk problems will restrict the sustainable development of the mortgage financing business of rural land management right. Therefore, this paper takes the mortgage financing of rural land management right in Wuhan City, Hubei Province as the research object, analyzes the specific practices, financing modes and achievements of the reform, and focuses on some of the risk problems in its development, and analyzes the mechanism of risk formation. Summed up the risk prevention and control measures have been taken. Finally, make further suggestions.
\end{abstract}

\section{Introduction}

With the gradual deepening of economic reform, the system of farmland property rights in China has been redesigned, and the property of rural land contractual management right has gradually been taken seriously. In order to activate rural capital, enhance the collateral property of rural assets and give play to the capital function of rural land property rights. In recent years, the Central Committee of the Communist Party of China and the State Council have successively promulgated relevant policies. In these reform policies, the focus is to sort out the relationship between rural land ownership,contracting right and management right,and to realize mortgage financing of rural contractual land management right,thereby giving farmers more property rights. Realizing the mortgage financing of rural contractual land management right not only helps to perfect the land system reform,but also has the practical significance of promoting the marketization of agriculture with the rural financial system.

The rural property right mortgage loan is an important innovation of the rural financial system, which is conducive to revitalizing the stock of rural assets and improving the utilization efficiency of rural land resources, which is of great significance to rural economy and rural financial development.However,as an innovative financial business, there are some risks and problems in the practice of rural property right mortgage loan.How to effectively identify and prevent risks has some value to promote rural financial security,agricultural production and operation and peasant life.Based on this,this article tries to discuss the risk problems encountered in the process of Wuhan rural property mortgage loan. 


\section{Analysis of Mortgage Financing Model of Rural Land Management Right in Wuhan}

\subsection{Wuhan Rural Comprehensive Property Exchange Institution status quo}

Wuhan Rural Comprehensive Property Exchange Institution was established on April 30, 2009,it is one of the earliest rural comprehensive property rights exchange institutions established in China.Reform and innovation is the soul of Wuhan Rural Property Exchange Institution.Since it was founded, the"three rights division" of land ownership,land contractual right and land management right is the most fundamental innovation.Mortgage guarantee is the most important innovation and risk prevention is the most crucial innovation.At the same time,market cultivation, system establishment,system construction and many other aspects of innovation.It is known as the "Wuhan mode."It is through a variety of innovations that,since its establishment eight years ago, Wuhan rural property exchange achieved effective results.A total of 2948 rural property transactions were organized, with a transaction value of 17.26 billion yuan,involving 1.343 million mu of rural land,benefiting 170,000 rural households; and a joint financial institution providing loans for rural comprehensive property rights to agricultural enterprises, cooperatives and breeding farms of 3.268 billion yuan.

Table 1 Main innovations of Wuhan Rural Comprehensive Property Exchange Institution

\begin{tabular}{|c|c|c|}
\hline Innovative content & Details & Practical measures \\
\hline \multirow{2}{*}{ Fundamental innovation } & \multirow{2}{*}{ Separation of powers } & Policy support \\
\hline & & $\begin{array}{l}\text { Explore the } \\
\text { “transaction-forensics-mortgage”mode }\end{array}$ \\
\hline \multirow{3}{*}{ Major innovation } & \multirow{3}{*}{ Mortgage guarantee } & Establish trading platform \\
\hline & & Build city circle \\
\hline & & Unified management mode \\
\hline \multirow{3}{*}{ Key innovations } & \multirow{3}{*}{ Risk prevention } & $\begin{array}{c}\text { Development of “rural property rights } \\
\text { mortgage registration system” }\end{array}$ \\
\hline & & Interest on mortgage lenders loans \\
\hline & & $\begin{array}{l}\text { Establishment of agricultural asset } \\
\text { management company }\end{array}$ \\
\hline
\end{tabular}

\section{2 operating mechanism of mortgage financing in rural land in Wuhan}

Wuhan rural property system reform is the main test of rural property mortgage financing,which is an important way to achieve rural assets into capital.Among them, the mode of mortgage financing of rural land management right is the key pilot project.

Specific process shown in Figure1:1 ffarmers transfer land management right to agricultural enterprises through the trading institution;(2)agricultural enterprises pay land rent to farmers;3trading institutions issued a certificate of ownership transactions to agricultural enterprises;4rural collective organization issue the document that the land is approved for mortgage and redistribution;(5)assessment agencies assess the value of land management right;(6)agricultural enterprises to apply for loans to financial institutions; (7)financial institutions to approve loans; 8if the loan is approved,the lender apply for registration of mortgages in the trading institution. 


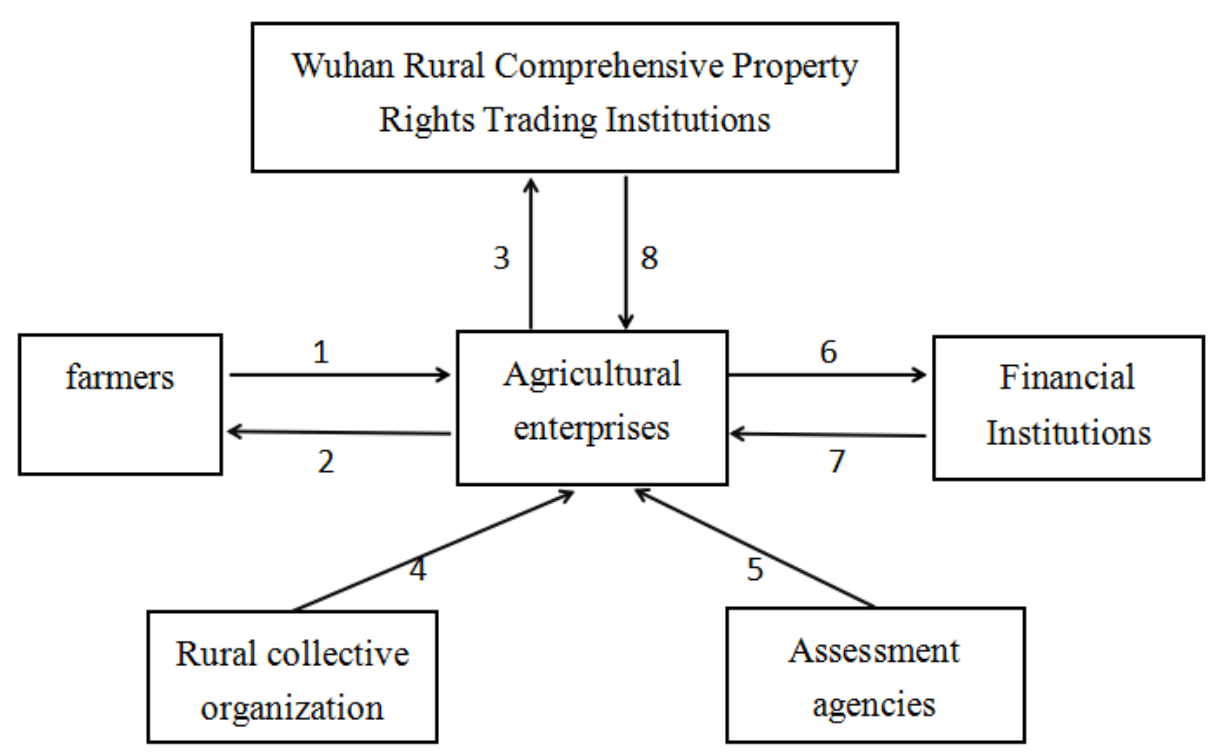

Fig 1 mortgage loan operating mechanism

\subsection{Main experiences of mortgage financing mode of rural land management right in Wuhan}

The main advantages of Wuhan mode include the following aspects.First,the process concentrated on trading institution,and the institution integrated resources, which could effectively reduce the transaction costs of farmers and enterprises.Second,the mortgage mode is open,attracting more investors through the release of information,such as large-scale agricultural enterprises. The introduction of businesses into the mortgage business has added vitality to the construction of rural financial markets.Third,this model can reduce the credit risk of financial institutions.The insitution regularly publishes the transaction price of land contractual management right.For financial institutions,standardized trading procedures,more symmetrical information and good supporting services will help protect their rights and interests.Fourth,the mode is conducive to raising the price of land transfer.As companies get mortgages,their willingness to consolidate their investment in land is stronger,and the total amount of land available for mortgage is limited,resulting in an increase in the price of land transfer.This mode has in fact reached the triple win effect of enterprises,farmers and financial institutions.These advantages are formed in continuous exploration and innovation,the main practices and experiences of Wuhan mode has the following major aspects.

\subsubsection{The government's attention}

Hubei provincial government issued relevant documents,clearly put forward the rural land "separation of powers" principle.It takes Wuhan Rural Property Exchange Institution as a leader to build the province's unified rural property rights trading platform.And set up a supervision and management institution for the circulation of rural property rights transactions,providing a guarantee for the normative operation of rural property rights trading markets.

2.3.2Perfect rural property rights transaction management service system

First of all,build a three-tier property market trading system.For the various types of property transactions in rural areas to provide venue facilities,information dissemination,organizational transactions,forensics and other services.The establishment of Rural Comprehensive Property Rights Exchange Institution in Wuhan City,the establishment of branches of rural property rights exchanges institution in the agriculture-related areas,authorized by the headquarter to carry out 
transactions,the establishment of rural integrated property rights transaction service station,responsible for the collection and submission of rural property rights transaction information.By 2016,a total of 5 district-level trading centers and 50 service stations for towns and cities have been established,forming a three-level market system of property rights.

Second,to build information technology service system.Explore the"Internet+"agricultural property transaction information technology.It has developed and deployed a rural property rights trading system,and all districts and township branches and headquarters are networked and interconnected so that online declaration,approval,trading,forensics and supervision can be realized.

Thrid,to build system of security system.To regulate the pilot work, have issued a number of legal documents.It defines the loan application conditions,loan interest rates,loan deadlines,loan processes,loan defaults and so on.

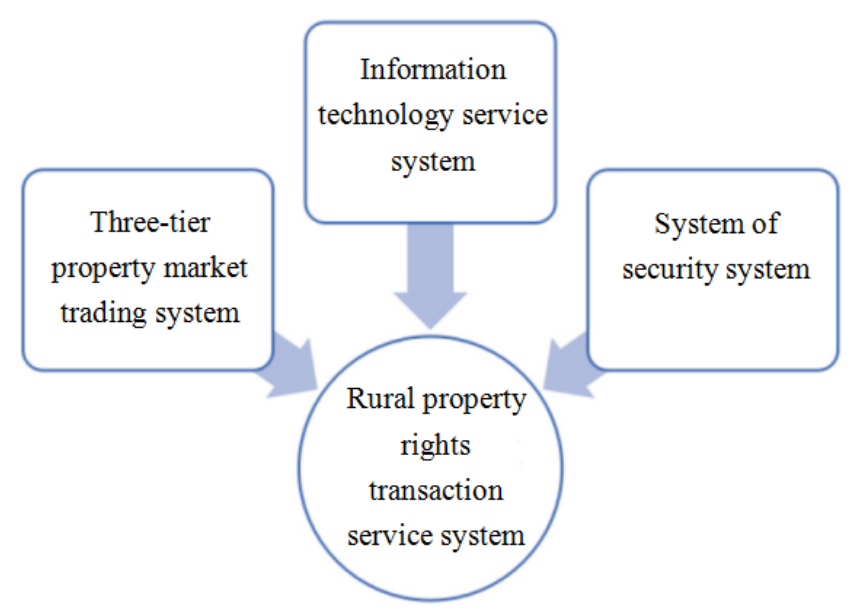

Fig 2 Rural property rights transaction service system

\subsubsection{Innovative mortgage method}

This mode is supported by the theory of "separation of ownership".The mode of handling procedures is "transaction - forensics - mortgage".It realizes the right of land management right in the part of land circulation transaction,and the transaction agency authenticates the transaction of land transfer and issues the transaction certificate.Based on the valuation of the value of land management right,fixed assets and crops attached to the land,the lender applies for the mortgage registration in the trading institution and the loan amount shall not exceed $50 \%$ of the value of the collateral.If loans can not be repaid,relying on the trading platform,the collateral will be listed and then circulated.

\section{Wuhan land contractual management right mortgage financing risk analysis}

\section{1 rural land management right mortgage financing risk subject}

3.1.1The main body of potential demand for mortgage financing mode of rural land management right

With the development of agricultural modernization,the scale management gradually replaced the fragmentation and decentralized management.In carrying out economic activities, farmers follow the principle of comparing the expected benefits with the expected costs. When the marginal benefit of farming is greater than that of non-agricultural industries,farmers are willing to flow into the land for agricultural production;on the contrary, they will flow out of the land.In the practice of rural 
property rights transactions,farmers can either directly enter the rural property rights trading platform for trading,or can also entrust others to deal with the rural property rights.

\subsubsection{The actual demand main body of mortgage financing mode of rural land management right}

According to the report,as of the end of 2016,Wuhan City carried out 631 mortgage financing businesses of rural land management right and 490 cases of mortgage rural land management right realized by the company,accounting for $77.66 \%$.There were 131 mortgage rural land management right led by family farms and cooperatives, accounting for $22.34 \%$.Thus, the main body of the demand for mortgage financing of rural land management right in Wuhan is mainly the rural operating enterprises.From the records of the transactions,both the number of transactions and the transaction amounts are obviously higher than those of other entities. The agricultural enterprises are the most active assignee.

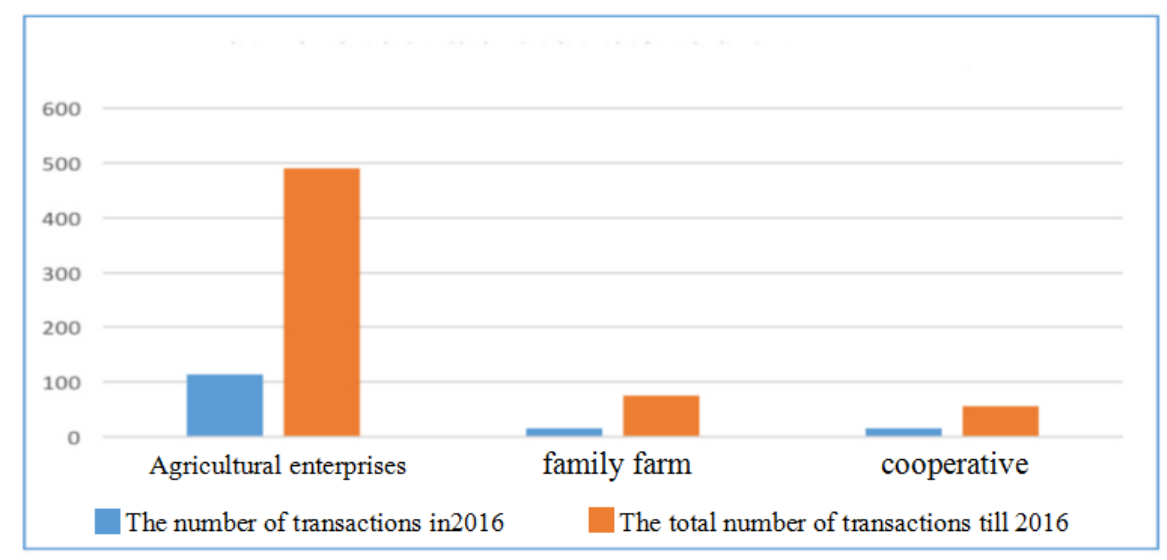

Fig 3 demand distribution of rural land mortgage financing in Wuhan

\subsubsection{The main body of mortgage supply for rural land management right}

In terms of lending institutions,although rural property exchange agencies have united a number of financial institutions with different ownership structures and sizes,Wuhan local financial institution-Wuhan Rural Commercial Bank has played a leading role.Under the guidance of the policy,the bank continued to innovate and developed such financial products as "right-interest loans"to meet the financing needs of agricultural production.According to the report,it shows that by the end of 2016,a total of 9 financial institutions in Wuhan have carried out the mortgage loan business of rural land management right,among which,Wuhan Rural Commercial banks issued a total of 2.826 billion yuan loans, a total of 512 strokes, accounting for $86.48 \%$ of the total loans.

Table 2 The main body of mortgage supply for rural land management right

\begin{tabular}{|c|c|c|c|c|c|c|c|c|c|}
\hline $\begin{array}{c}\text { Financial } \\
\text { institutio } \\
\text { ns }\end{array}$ & $\begin{array}{c}\text { Wuhan } \\
\text { Rural } \\
\text { Comm } \\
\text { ercial } \\
\text { Bank }\end{array}$ & $\begin{array}{c}\text { Jiangxia } \\
\text { Minsheng } \\
\text { Township } \\
\text { Bank }\end{array}$ & $\begin{array}{c}\text { Hank } \\
\text { ou } \\
\text { Bank }\end{array}$ & $\begin{array}{c}\text { Bank } \\
\text { Of } \\
\text { China }\end{array}$ & $\begin{array}{l}\text { Bank } \\
\text { of } \\
\text { Comm } \\
\text { unicati } \\
\text { ons }\end{array}$ & $\begin{array}{c}\text { Ao } \\
\text { chang } \\
\text { small } \\
\text { loan } \\
\text { company }\end{array}$ & $\begin{array}{c}\text { Agricu } \\
\text { ltural } \\
\text { Bank } \\
\text { of } \\
\text { China }\end{array}$ & $\begin{array}{c}\text { Wuhan } \\
\text { agricult } \\
\text { ural } \\
\text { guarant } \\
\text { ee } \\
\text { Co.,ltd. }\end{array}$ & $\begin{array}{c}\text { Minsh } \\
\text { eng } \\
\text { Bank }\end{array}$ \\
\hline number & 512 & 80 & 25 & 2 & 2 & 4 & 3 & 1 & 2 \\
\hline
\end{tabular}

The groups involved in the operation of rural land mortgage loans have a completely different impact on general loan behavior,which is related to the separation of the three rights of farmland ownership.Once the farmland mortgage defaults, In addition to the mortgagors and creditors,it also 
involves peasants who have the right to use and the right to operate the land,and they are the core interests of peasants. Therefore,the main subjects of risk involved in the mortgage financing of rural land management rights in Wuhan are farmers,agricultural enterprises,local rural financial institutions and guarantee agencies.

\section{2 the main risk}

Different risk subjects involve different risk issues.Based on the different risks,the author summarizes the risks encountered in the mortgage loan process of land contractual management right in Wuhan and attempts to find out the main mortgage risks it faces,and analyzes the main reasons for the formation of various types of risks.

\subsubsection{Risks based on farmers' perspectives}

With the development of agricultural modernization,the agricultural operation in Wuhan tends to be modest and large-scale operation. The expansion of the scale of this farmland is accompanied by a shift from the traditional peasant household to the main body of the scale of management of agricultural land.However,the long-term direct renting of farmer land by large-scale management entities may lead to the non-food and non-agriculturalization of rural land.Moreover,in the mode of mortgage financing for farmland management right in Wuhan,the main body of scale management of leasing land from farmers is to establish contact with financial institutions. The main body of the scale of agricultural operation get the mortgage loans,once the mortgage risk,a large area of land management right may be assigned to the bank,the bank through the land exchange institution to transfer the land management right.This will introduce a new type of management entity that may violate the original contract,such as not paying rent on a regular basis,changing farmland use,overusing fertility and so on.This has damaged the interests of peasants and triggered disputes,largely affecting the stability of rural society.

\subsubsection{Risks based on agricultural enterprises}

First of all,the positioning of agricultural enterprises.In the process of pushing forward the reform of rural property rights, Wuhan vigorously pushed forward the mortgage loan of rural land management right and supported the establishment of a new type of agricultural management entity. However,in the actual investigation,some enterprises blindly expand the scale of operation and obtain loans through preferential policies.However,this scale of operation goes beyond the scale of controlling the cost and profit,resulting in risks in the production and operation of enterprises.In addition,some enterprises have no experience in agricultural management at all.Their investment in agricultural production blindly enters into agricultural production for the sole purpose of agricultural-related preferential policies and speculation,and there is no genuine agricultural work ethic,which often leads to mistakes in decision-making and business risks.

Second,agricultural management risks. With the development of agricultural modernization and driven by economic interests, the desire of agricultural enterprises in Wuhan to expand their scale of operation and carry out agriculture-related projects,such as special agricultural products, breeding and developing agricultural tourism has become increasingly strong.In addition,the promotion of laws and policies,the reform and trial of rural property rights mortgage financing and the innovation of financial products in financial institutions have eased the urgent needs of raising funds for agricultural enterprises in Wuhan.Relatively speaking,agricultural enterprises have the characteristics of high reputation and professional agricultural technicians,large scale and strong anti-risk ability.However,due to the special nature of agricultural production and management,long cycle,slow,high risk,often encounter natural or market risk,low return on investment in agricultural 
production,which makes the frequent occurrence of mortgage loans.During the reform of property rights mortgage financing in Wuhan,several cases of "mortgage loan risks" have been handled, including the leading enterprises and professional cooperatives.These cases involve loans ranging from 1 million to 10 million,involving more than a thousand acres of land.The reasons for the non-repayment are mostly poor management.

Table 3 case of mortgage risk

\begin{tabular}{|c|c|c|c|c|c|}
\hline Company name & $\begin{array}{c}\text { Main } \\
\text { business }\end{array}$ & $\begin{array}{l}\text { Mortgage } \\
\text { method }\end{array}$ & $\begin{array}{c}\text { Loan } \\
\text { amount }\end{array}$ & Main reason & $\begin{array}{c}\text { Ways to solve the } \\
\text { problem }\end{array}$ \\
\hline $\begin{array}{c}\text { Xinnong Agricultural } \\
\text { Science and } \\
\text { Technology } \\
\text { Development } \\
\text { Corporation } \\
\end{array}$ & $\begin{array}{c}\text { Aquatic } \\
\text { products、 } \\
\text { breeding }\end{array}$ & $\begin{array}{l}\text { Land } \\
\text { contracting } \\
\text { rights+ground } \\
\text { attachments }\end{array}$ & $\begin{array}{l}\text { More than } \\
500 \text { million }\end{array}$ & $\begin{array}{c}\text { Poor } \\
\text { management }\end{array}$ & $\begin{array}{l}\text { Extend the } \\
\text { repayment period }\end{array}$ \\
\hline $\begin{array}{l}\text { Wuhan agricultural } \\
\text { breeding company }\end{array}$ & $\begin{array}{l}\text { Agricultura } \\
\text { l breeding }\end{array}$ & $\begin{array}{c}\text { Land } \\
\text { contracting } \\
\text { rights }\end{array}$ & One million & $\begin{array}{c}\text { Poor } \\
\text { management }\end{array}$ & $\begin{array}{l}\text { New investor } \\
\text { joins }\end{array}$ \\
\hline
\end{tabular}

\subsubsection{Risk based on the perspective of financial institutions}

First,risk prevention and compensation mechanism risks.In order to reduce the risks that the pilot projects of rural property rights mortgage financing may face,Wuhan City has adopted some risk prevention and compensation mechanisms.For example,the risk compensation funds have been set up to appropriately compensate the financial institutions for default loan losses.However,at present,the scale of risk compensation funds is only 30 million yuan. When financial institutions encounter the risk of repayment,the compensation and sharing mechanisms may have a limited role. And the establishment of risk control and compensation mechanisms is essentially a measure of the supply of rural financial institutions risk subsidies,the purpose is to increase their willingness to provide agricultural land mortgage loans.Therefore,the concrete effect of credit risk is minimal.

Second,the risk of collateral.The key to the success or failure of a farmland mortgage loan depends on whether the innovative collateral function of farmland management can be realized and its degree of realization.As a top-down financial innovation,with the improvement of relevant policies and legal documents, the rural land management right can theoretically be qualified as collateral.However,in the process of practice,the collateral property is affected by the transaction costs such as land value assessment costs, disposal costs and the disposal of land after default risk. The survey found that in the aspect of land value assessment,Wuhan Rural Commercial Bank, based on the principle of market pricing and the rent and production and construction costs involved in the land transfer,is the basis for assessing the value of the land and the main repayment fund flow.And at the same time,introduce professional assessment agencies to require that the valuation of mortgages must be jointly approved by assessment experts,agricultural experts,handling banks and borrowers.However,there is a certain problem for the evaluation of the value of agricultural land management right because there is no uniform regulation for the evaluation criteria and there is a certain subjective difference among the assessors.

In the long run,the main risks facing financial institutions are the disposal of mortgages. Because banks encounter different problems from ordinary mortgaged assets in the process of asset disposal,direct agricultural management does not conform to the economic rationality of financial institutions.Therefore,financial institutions should redistribute farmland through circulation mechanisms.However,the disposal of land management right is very difficult.On the one hand, there are positive transaction costs for financial institutions in disposing of the collateral of the loan in 
default,for example,the state exercises control over the use of rural land,and rural land can only be used for agricultural activities,resulting in only the main agricultural operation being transferred to the land management right,increasing the cost of changing and re-circulating property rights of the mortgage property,and increasing the cost of the financial institutions disposal of collateral.On the other hand,since the rent of peasants is not bought out,it is usually paid in one year.If the collateral is not successfully circulated,financial institutions will also face the problem of paying rent to peasants.

\subsubsection{Risk based on the guarantor's perspective}

Wuhan government promotes the establishment of a bank-insurance interaction mechanism combining rural credit with agricultural guarantee and agricultural insurance. When applying for a loan,some agricultural enterprises introduce a guarantee mechanism and find individuals or companies with good credit to guarantee their loans. When an enterprise is unable to repay the loan, it may bring a certain guarantee risk to the guarantee institution, This risk has a direct impact on the willingness of the security and insurance institutions to participate.

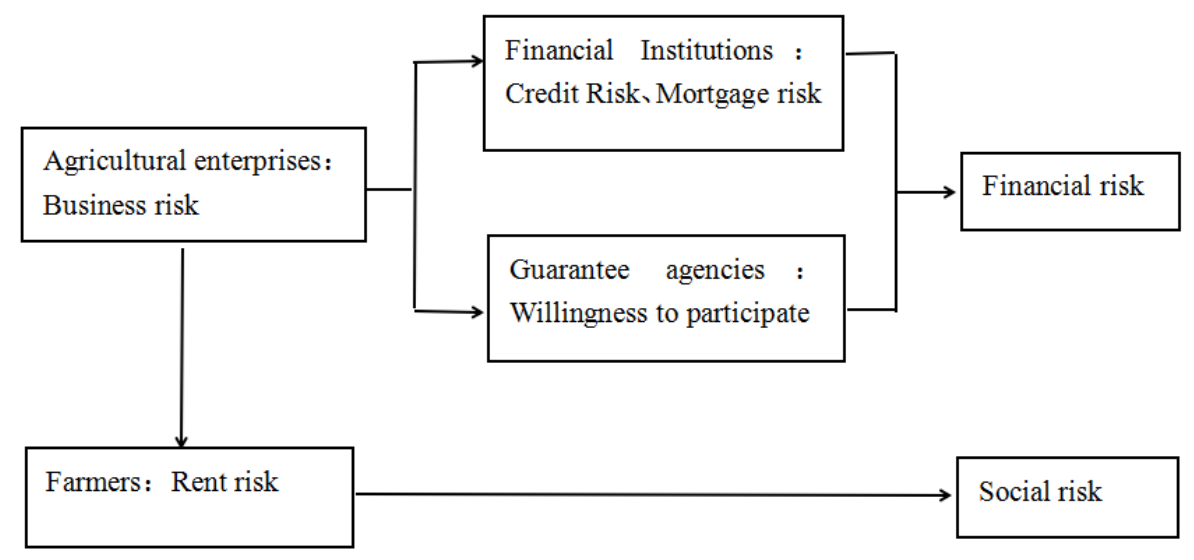

Fig 4 The main risk of mortgage loan of Wuhan rural land management right

\section{3 risk prevention and control measures}

With the advancement of"two rights"pledging pilot projects,the preconditions for the capitalization of agricultural land, the self-reliant liquidity and the collateral function are gradually perfected,and the external conditions of mortgage financing under the land contractual management right are guaranteed.In this context,the reform of rural financial property rights based on rural property rights trading institutions in Wuhan City has achieved some success after several years of exploration.It effectively activated the rural factor markets and promoted rural land circulation and scale management.In response to the risks that emerged during the reform process,the Wuhan municipal government and financial institutions adopted a series of countermeasures to better push forward the reform of rural property finance. 
Table 4 Precautionary measures against mortgage risk of land management right in Wuhan

\begin{tabular}{|c|c|c|c|}
\hline actors & Targeting factors & measures & effect \\
\hline \multirow{4}{*}{ goverment } & \multirow{3}{*}{ Disposal of collateral } & $\begin{array}{c}\text { Design risk compensation } \\
\text { mechanism }\end{array}$ & $\begin{array}{c}\text { Compensation for bank } \\
\text { credit losses }\end{array}$ \\
\hline & & $\begin{array}{c}\text { Establish an interactive } \\
\text { mechanism between banks } \\
\text { and insurance institutions }\end{array}$ & $\begin{array}{l}\text { Strengthen the collateral } \\
\text { insurance }\end{array}$ \\
\hline & & $\begin{array}{c}\text { Set up a rural asset } \\
\text { management company }\end{array}$ & $\begin{array}{c}\text { Disposal of } \\
\text { non-performing assets }\end{array}$ \\
\hline & Repeat the mortgage & $\begin{array}{c}\text { Improve the registration } \\
\text { database of rural property } \\
\text { rights }\end{array}$ & $\begin{array}{l}\text { Clear ownership of } \\
\text { property and strenghen } \\
\text { dynamic management }\end{array}$ \\
\hline \multirow{2}{*}{$\begin{array}{l}\text { Rural property rights } \\
\text { trading institutions }\end{array}$} & collateral & $\begin{array}{c}\text { Issued a certificate of } \\
\text { authenticity }\end{array}$ & $\begin{array}{l}\text { Guarantee the } \\
\text { effectiveness of mortgage }\end{array}$ \\
\hline & $\begin{array}{c}\text { Repeat the transfer of } \\
\text { land risks }\end{array}$ & $\begin{array}{c}\text { Trading collateral in the } \\
\text { market }\end{array}$ & $\begin{array}{c}\text { Protection of bank rights } \\
\text { and interests }\end{array}$ \\
\hline \multirow{3}{*}{ Financial institutions } & Credit risk & $\begin{array}{l}\text { For different subjects,a } \\
\text { single or combination of } \\
\text { credit products loans }\end{array}$ & Strengthen credit utility \\
\hline & Loans subjects & $\begin{array}{l}\text { Selection of high-quality } \\
\text { customers,docking with } \\
\text { the new main agricultural } \\
\text { business }\end{array}$ & $\begin{array}{l}\text { Improve repayment } \\
\text { ability }\end{array}$ \\
\hline & Loan period & $\begin{array}{l}\text { Appropriate relaxation of } \\
\text { the loan period }\end{array}$ & $\begin{array}{l}\text { Relieve repayment } \\
\text { pressure }\end{array}$ \\
\hline
\end{tabular}

\section{Shortcomings and suggestions}

During the reform of rural property finance in Wuhan,the government,financial institutions, agricultural enterprises and other subjects have done corresponding work both in the preparatory work and in the latter stage of risk prevention and control.It has made a significant contribution to promoting the development of the rural financial system.However,there are some problems.First of all,the problem of government's function.During the reform of Wuhan's rural property system,the government funded the establishment of rural property rights trading institutions and set up risk compensation funds to promote the establishment of an interactive mechanism for banks and insurance institutions.This is the major force in resolving the risks of land mortgages.In the short term, it can reduce certain financial risks and promote the development of the mortgage loan business of land management right.However,in the long run,as the rural financial market develops, the government's role should be to remedy the market failure.Therefore,the functional orientation of the government is worth considering.Second,financial institutions bear the ultimate risk.Risk prevention is an everlasting consideration for financial institutions.For the land as a special collateral, Wuhan financial institutions to prevent and dispose of the process is not perfect.Thirdly, With the improvement of policies and encouragement of the government,the extensive promotion of rural land mortgage loans has strengthened the will of operators to expand their scale. However,It is necessary to consider whether expanding the scale of operation or enhancing the investment is conducive to the order of agricultural production and management.

Based on the above analysis,this article put forward further countermeasures and suggestions on the basis of this,with a view to its better development.

First of all,when the reform and development reach a certain stage,the orientation of the government needs to be changed.It is necessary not only in the business process intervention,but also in risk mitigation,it should gradually shift to market-oriented.Because the farmland mortgage 
loan promoted by the administrative force will be deviated from the actual situation of agricultural development to a certain extent and will not be conducive to the establishment of market rules. Only by implementing market-based collateralization of farmland instead of mainly by administrative forces will we be able to give full play to the leverage effect of rural land and activate rural financial markets.

Second,at present,in the process of Wuhan rural land management right of the mortgage loan,the leading role is local financial institutions.To further expand the supply of the main body,the introduction of more different types of financial institutions,to avoid excessive concentration of rural property rights.In addition,financial institutions should strengthen the design of mortgage rules and risk management mechanisms.For example,It is necessary to increase the monitoring of the operation and management of the mortgage farmland during the mortgage of the farmland management right by the borrower and keep the borrower informed of the operation and management of agricultural land and the sales of agricultural products and other information. When it is found possible credit risk,the loan can be stopped or withdrawn in advance.

Finally,the agricultural enterprises should comprehensively consider the particularity of farmland,the weakness of agriculture and the livelihood of peasants and other factors,and avoid blindly expanding the scale of agricultural operation and agricultural production activities and strengthening the evaluation and analysis of the feasibility of agricultural project investment in order to obtain good expected investment return,to avoid credit risk.

\section{References}

[1]Gao Ying. The Study on Risk Prevention System of the Mortgage of Land Contractual Management Right[D].Central China Normal University,2015.

[2]Yang Qicai. Realization and Risk of Mortgage Loan of Farmland Management Right: Practice and Case Analysis[J]. Issues in Agricultural Economy, 2015(10).

[3]Chen Yongqing.Analysis of the Risky Factors of the Mortagage Financing of Rural Land Management Right[J].Shanghai Economic Research,2016(7).

[4]Zhang Longyao. Analysis of Mortgage Financing Reform of Peasants' Land Contract Management Right[J].Issues in Agricultural Economy,2015(2).

[5]Pan Wenxuan.On The Risks of Rural Land Management Right Mortgage Loan[J].Journal of Nanjing Agricultural University,2015(15).

[6]Zeng Qingfen. Rural land mortgage financing model and regional experience[J].Journal of Central University of Finance and Economics,2016(1). 